
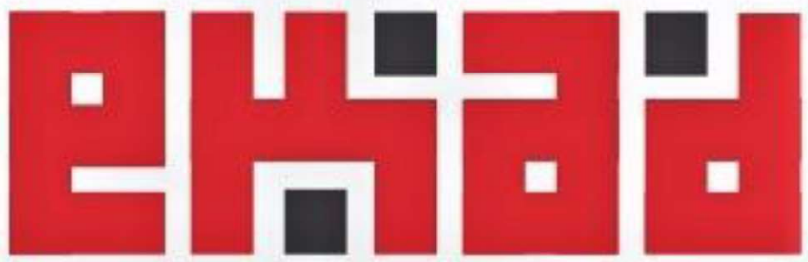

INTERNATIONAL JOURNAL OF LANGUAGE, LITERATURE AND CULTURE RESEARCHES

МЕЖДУНАРОДНЫЙ ЖУРНАЛ ЛИНГВИСТИЧЕСКИХ, ЛИТЕРАТУРОВЕЛЧЕСКИХ И КУЛЬТУРОЛОГИЧЕСКИХ ИССЛЕЛОВАНИЙ

Vol: 4, Issue: 2, 2021

Sayfa-Page: $320-333$

E-ISSN: 2667-4262

\title{
ПЕРВЫЕ УТОПИЧЕСКИЕ СНЫ В ТУРЕЦКОЙ И РУССКОЙ ЛИТЕРАТУРАХ
}

\section{THE FIRST UTOPIAN DREAMS IN TURKISH AND RUSSIAN LITERATURE}

\section{Yasemin GÜRSOY*}

\begin{tabular}{|c|c|}
\hline Информация о статье & АННОТАЦИЯ \\
\hline $\begin{array}{l}\text { Получена: } 16.09 .2021 \\
\text { Принята: } 15.11 .2021\end{array}$ & \multirow{3}{*}{$\begin{array}{l}\text { Цель исследования - сравнительный анализ первых утопических снов в турецкой и } \\
\text { русской литературах. Предметами исследования являются повести «Сон “Счастливое } \\
\text { общество” Александра Петровича Сумарокова и «Сон» Намыка Кемаля. } \\
\text { Актуальность выбора темы обусловлена, во-первых, тем, что сравнительный анализ } \\
\text { турецкой и русской утопий малоизучен. Во-вторых, тема показывает, что сны в жанре } \\
\text { утопии используются в качестве мотива в разных эпохах и культурах. В статье кратко } \\
\text { рассказывается о появлении жанра утопии в турецкой и русской литературах. } \\
\text { Анализируются социальные и культурные различия через утопические сны двух } \\
\text { авторов. В работе предпринимается попытка передать черты, которые русские и } \\
\text { турецкие писатели ищут в идеальном обществе, с помощью цитат из произведений А. } \\
\text { Сумарокова и Н. Кемаля. В результате доказано, что тема поиска идеальной формы } \\
\text { государства и жанр утопии используются в литературе разных обществ и периодов, и } \\
\text { утопические сны - идеальный способ для этого жанра. }\end{array}$} \\
\hline $\begin{array}{l}\text { Ключевье слова: } \\
\text { Утопия, } \\
\text { утопический сон, } \\
\text { Александр Сумароков, } \\
\text { Намылк Кемаль. }\end{array}$ & \\
\hline $\begin{array}{l}\text { Научно-исследовательскаяа } \\
\text { статья }\end{array}$ & \\
\hline
\end{tabular}

Received: 16.09 .2021

Accepted: 15.11 .2021

Keywords:

Utopia,

utopian dreams,

Alexander Sumarokov,

Namık Kemal.

Research

Research Article
The purpose of the study is a comparative analysis of the first utopian dreams in Turkish and Russian literature. The subjects of the research are the stories Dream of a Happy Society by Alexander Petrovich Sumarokov and The Dream by Namık Kemal. The relevance of the topic choice is due, firstly, to the fact that the comparative analysis of the Turkish and Russian utopias is insufficiently studied. Secondly, the topic shows that dreams in the genre of utopia are effective in different eras and cultures. The article briefly describes the emergence of the utopia in Turkish and Russian literature. In the analysis section social and cultural differences are examined through utopian dreams of the two authors. The features that Russian and Turkish writers who are looking for in an ideal society are trying to convey with quotations from the works of A. Sumarokov and N. Kemal. As a result, it is proved that the theme of the search for the ideal form of the state and the genre of utopia are used in the literature of different societies and periods, and utopian dreams are the ideal way for this genre.

* Dr. Öğr. Üyesi., Trakya Üniversitesi, Edebiyat Fakültesi, Balkan Dilleri ve Edebiyatları Bölümü, Rus Dili ve Edebiyatı Ana Bilim Dalı, Edirne / Türkiye, E-mail: yasemingursoy@trakya.edu.tr.

ORCID (D) https://orcid.org/0000-0003-2103-3410.

Bu makaleyi şu şekilde kaynak gösterebilirsiniz / To cite this article (APA):

Gürsoy, Yasemin (2021). "Первые Утопические Сны в Турецкой и Русской Литературах". Uluslararası Dil, Edebiyat ve Kültür Araştırmaları Dergisi (UDEKAD), 4 (2): 320-333. DOI: https://doi.org/10.37999/udekad.996292. 
Özet

Çalışmanın amacı Rus ve Türk edebiyatlarındaki ilk ütopik rüyaların karşılaştırmalı bir analizini yapmaktır. Araştırma konusu olarak Aleksandr Petroviç Sumarokov'un 'Mutlu Toplum' Rüyası (Сон 'Счастливое общество") ve Namık Kemal'in Rüya eserleri belirlenmiş̧tir. Seçilen konu, Türk ve Rus ütopyalarının karşılaştırmalı analiziyle ilgi yapılan araştırmaların az olması nedeniyle günceldir. İkinci olarak ise konu özellikle ütopya türünde rüyaların farklı dönem ve kültürlerde etkili olduğunu göstermektedir. Makalede Türk ve Rus edebiyatlarında ütopya türünün ortaya çıkışından kısaca bahsedilmektedir. Analiz bölümünde, iki yazarın ütopik rüyaları aracılığıyla sosyal ve kültürel farklılıkları ele alınmaktadır. Türk ve Rus yazarların ideal bir toplumda aradıkları özellikler, A. Sumarokov ve N. Kemal'in eserlerinden yapılan alıntılarla aktarılmaya çalışılmaktadır. Sonuç olarak, ideal devlet biçimini arama teması ile ütopya türünün farklı toplum ve dönem edebiyatlarında her zaman kullanıldığı ve ütopik rüyaların bu tür için işlevsel bir metot olduğu gösterilmektedir.

Anahtar kelimeler: ütopya, ütopik rüya, Aleksandr Sumarokov, Namık Kemal.

\section{Extended Abstract}

This article briefly describes the emergence of the genre of utopia in Russian and Turkish literature. The comparative analysis is carried out based on the works "Dream of a Happy Society" by Alexander Sumarokov and "The Dream" by Namık Kemal, which are the first dream utopias in Russian and Turkish literature. The work attempts to convey the features that Russian and Turkish writers are looking for in an ideal society, based on quotations from works.

As in world literature, there are examples of utopia in Turkish and Russian literature. The genre of utopia in Russian literature begins to actively develop since the 18th century, but the primary sources of the genre were ancient Russian folk tales, legends. The first utopian works in Turkish literature appeared in the 19th century. It is worth noting that the genre of utopia appears late in Turkish literature and differs from functioning in other cultures. In Russian literature, under the influence of a religious text and teaching, the genre of utopia appears and continues to develop, while for Turkish literature this is happening in the opposite direction. In particular, the fact that the Ottoman state was one of the leading powers of the era made writers and society an impression that they lived in an ideal state. This situation changed with the collapse of the Ottoman Empire, and the first utopian works in Turkish literature appear as dreams with socio-political content.

Being the first authors to use the dream motif in their utopian works, A. Sumarokov (1717-1777) and N. Kemal (1840-1888) are important writers for their national literature. Both authors see problems in social order and try to find solutions to these problems with their own methods, that is, through their works. Sumarokov's story "Dream of a Happy Society" was published in 1759 in the magazine "Trudolubivaya Pchela". N. Kemal wrote "The Dream" during his exile in Famagusta in 1872.

In this article, which compared two different utopias from world literature, we came to the following conclusions. N. Kemal primarily criticizes the society of his era. He not only dreams but also explains what is needed to realize dreams. He believes that his idealized country can exist with freedom, will of the people, government, responsible work for everyone, and equality. He does not describe the ideal country in detail, but he especially emphasizes technological advances, the importance of education, and increased welfare. A. Sumarokov begins to talk about an ideal society without criticizing or touching on the problems of his era. He also does not indicate what needs to be done for the emergence of an ideal society. He provides a recipe for a happy society, describing the general characteristics of the ideal statesman, the system of government and justice, the army, and society.

As a result, any literary work of the same genre is unique, because the periods and situations in which it was written are different. "Dream of a Happy Society" and "The Dream", which are examples of the genre of utopia, have many differences, although they were written in the same genre. This situation is a concrete example of the relationship of literature to tradition and society. Factors such as the ideology and personal life of the author, the social and political conditions of the era, affect the works. In addition, this article once again demonstrates the importance of the search for the ideal society by authors in different societies and periods and the eternity of the genre of utopia. Prospects for further research can be designated as identifying differences and similarities between 
Russian and Turkish literature through comparative research, as well as a more detailed study of the development of the genre of utopia in both literatures.

\section{Введение}

C тех пор, как человечество задумалось о создании порядка на земле, оно также начало искать идеальную форму государства. Выбранные формы государства не затрагивают всех членов общества, а также полностью исключают некоторых членов и вытесняют их из общества. Индивид, оказавшийся в одиночестве, впадает в духовную пустоту, и в результате этого проявляются мечты, то есть утопические мысли (Yetkin 2020: 64). Растущее недовольство людей существующим порядком и процесс поиска идеальных моделей общества попадают в порочный круг. Искать идеальный социальный порядок и управление - это тема, о которой задумывается все человечество, а также и мыслители. В целом мыслители также начинают думать об утопии, когда их исключают из общества. Профессор Борис Егоров (2006: 5) подчёркивает, что авторы утопии часто пишут свои произведения в тюрьме, и объясняет это тем, что автор был лишен общественной жизни и деятельности в этом процессе. К этой идее можно добавить и авторов в изгнании. Первым, кто обратился к теме с произведением «Государство», стал известный философ Платон, а роман «Утопия», который дал этому жанру свое название, написан Томасом Мором. Известно, что оба мыслителя испытывали проблемы с управлением и обществом в то время, когда они жили.

Значение слова утопия в словаре даётся в виде «законопроекта или мысли, которые невозможно реализовать» (TDK: 2021). Термин «утопия» ведёт своё происхождение от греческого «ои́»- нет и «то́лоц» - место, и значит место, которого нет, а с романом Томаса Мора это слово приобретает значение «воображаемой страныл» (Nişanyan 2021). «Утопия - это эстетическая проблема, которую автор рассматривает в своей работе, основываясь на идее создания альтернативного сочиального дизайна против существующего» (Каaаса 2010: 66). Как и в мировой литературе, в турецкой и русской литературах существуют примеры жанра утопии. Стоит отметить, что в турецкой литературе жанр утопии появляется поздно и отличается от функционирования в других культурах. На данный момент вновь наблюдается влияние структуры общества, культуры, управления и исторического процесса на литературу.

Профессор В. Святловский (2015: 9) говорит, что «Золотые сны утопии скрашивают серую прозу жизни и вызывают стремление вперед, к чарующим далям грядущего. Они - дыхание романтизма, но не в минувшем, а в будущем. Они - сказки грядущего.» Сны являются одним из важнейших элементов жанра утопии. Авторы утопии прибегают для защиты от давления, критики и цензуры государства к сновидению. И поскольку сон рассматривается как бессознательное действие, то, что происходит в этом случае, кажется более невинным. Тот факт, что автор творит свою утопию особенно в сценах сновидений, позволяет ему более свободно и комфортно выражать свои идеи.

В этой статье кратко рассказывается о появлении жанра утопии в русской и турецкой литературах. Сравнительный анализ проводится по произведениям «Сон “Счастливое общество” Александра Сумарокова и «Сон» Намыка Кемаля, которые являются первыми утопическими снами в русской и турецкой литературах. В работе 
предпринимается попытка передать черты, которые русские и турецкие писатели ищут в идеальном обществе, на основании цитат из произведений.

\section{Утопии в русской и турецкой литературах}

Жанр утопии в русской литературе начинает активно развиваться с XVIII века, но «первочсточниками жанра были древнерусские фольклорные сказания, легенды и хождения〉 (Тараканова 2009: 39). Д. В. Бугров (2001: 31) объясняет это тем, что «история русской утопической литературы неразрывно связана с трагической судьбой России». Первые утопические произведения в турецкой литературе появились спустя почти столетие в XIX веке. В русской литературе под влиянием религиозного текста и учения жанр утопии появляется и продолжает свое развитие, в то время как для турецкой литературы это происходит в противоположном направлении. В частности, тот факт, что Османское государство являлось одной из ведущих держав эпохи, произвёл на писателей и общество впечатление, что они живут в идеальном государстве. Отсутствие «желания создать альтернативный мир или изменить и воспроизвести данный мир в литературном измерении из-за мысли о том, что мир является совершенным в своей сути», в исламе задерживает появление жанра утопии в турецком обществе (Canbaz 2012: 65). Эта ситуация меняется в процессе распада Османской империи, и первые утопические произведения в турецкой литературе появляются как сны с социальнополитическим содержанием.

Многие философы высказывают мнение, что утопизм лежит в основе русской ментальности и Э. Я. Баталов добавляет: «В России утопия всегда чувствовала себя как дома» (Митина 2013: 15). Первые утопические произведения в русской литературе появляются в XVIII веке: «Путешествие в землю Офирскую г-на С... шведского дворянина» М.М. Щербатова, «Сон “Счастливое общество”» А.П. Сумарокова, «Арфаксад. Халдейская повесть» П.М. Захарьина, «Сон» А.Д. Улыбышева. Интеллигенция видит, что в XIX веке Россия отстаёт от Запада в таких областях, как мировоззрение, государственное строительство и материальное производство, и начинает писать социалистические утопические произведения (Веремчук - Сорокин 2017: 9). Некоторые примеры включают «Европейские письма» и «Земля безглавцев» В.К. Кюхельбекера, «4338 Год» В.Ф. Одоевского, «Тарантас» В.А. Соллогуба, «Что делать?» Н.Г. Чернышевского, «Сон» А.Д. Улыбышев, «Сон смешного человека» Ф.М. Достоевского. Для русской литературы XX век - период разрыва, и особенно в течение первых 30 лет наблюдаются произведения этого жанра: «Через полвека» С.Ф. Шарапова, «Красная Звезда» А.А. Богданова, «Вечер в 2217 году» Н.Д. Федорова, «Путешествие моего брата Алексея в страну крестьянской утопии» А.В. Чаянова, «Республика Южного Креста» В.Я. Брюсова, «Страна Гонгури» В. Итина, «Мы» Е.И. Замятина, «Аэлита» А.Н. Толстого, «Трест Д.Е.» И.Г. Эренбурга, «Грядущий мир. 1923-2123» Я. Окунева, «Через 1000 лет» В.Д. Никольского, «За чертополохом» П.Н. Краснова, и др. «В 1930-е годы отечественная литературная утопия переживает спад: утверждающийся социалистический реализм не способствовал её дальнейшему развитию. Одним из последних образцов литературы подобного рода становится роман Я.Л. Ларри «Страна счастливых» (1931) - яркий пример коммунистической утопии» (Юрченко 2018: 195). До середины 1950-х годов не появляются новые произведения утопического жанра. Во второй половины XX века и особенно в периоде перестройки многие произведения 
написаны в жанре утопии: «Туманность Андромеды» И.А. Ефремова, «Завтра в России» Э. Тополя, «Иное небо» А. Лазарчука, «Полдень, XXII век» А.Н. и Б.Н. Стругацких, «Гравилет “Цесаревич”» В. Рыбакова, «Вариант “И”» В. Михайлова. С начала XXI века до наших дней жанр утопии продолжает свое развитие в таких произведениях как «Сверхдержава» А. Плеханова, «Конкистадор» Д. Володихина, «Эвакуатор» и «ЖД» Д. Быкова, «2008» С. Доренко, «2018» О. Славниковой, «Заложник» А. Смоленского и Э. Краснянского, «День опричника» В. Сорокина и др.

Произведения с утопическими особенностями в турецкой литературе начинают появляться со второй половины XIX века. C XX века чаще прибегают к утопии с влиянием исторических и общественных событий. Стоит отметить, что произведения в турецкой литературе сами по себе не несут утопических черт, часто переплетаются с фантастическими и научно-фантастическими жанрами. Среди утопических произведений, написанных в XIX веке, можно показать «Сон» (Rüya) Зия-Паши, «Воображаемая жизнь» (Hayat-1 Muhayyel) Хусейна Джахита и «Воображаемая жизнь» (Ömr-i Muhayyel) Тевфика Фикрета. Количество утопических произведений увеличивается после начала XX века. «Тот город» (O Belde) Ахмета Хашима, «Новый Туран» (Yeni Turan) Халиде Эдип, «Фетрет» (Fetret) Али Кемаля, «Махди» (Mehdi) Омара Сейфеттина, поэма «Красное яблоко» (K1z1l Elma) и повесть «Где красное яблоко» (Kizil Elma Neresi) Зия Гёкальпа имеют утопические черты. Первая работа в турецкой литературе республиканского периода (1923-1940) - роман «В стране свободных людей» (Serbest İnsanlar Ülkesinde) Ахмеда Агаоглу. Важными примерами являются произведения «Небесная страсть» (Semavi İhtiras) Раифа Неждета Кестелли, «Анкара» (Ankara) Якупа Кадри Караосманоглу, «Возвращение на родину» (Yurda Dönüş) Мемдуха Шевкета Эсендала, «Мы одни» (Yalnızız) Пейами Сафа, «Земля просыпается: Воспоминания учителя бесхлебной деревни» (Toprak Uyanırsa: Ekmeksizköy Öğretmeninin Hatıraları) Шевкета Сюрея Айдемира, «Разие» (Raziye) Мелиха Джевдета Андая и «Завтра завтра» (Yarın Yarın) Пынар Кюр. После 1980-х годов чаще встречаются произведения, носящие утопические черты. Можно сказать, что политическая обстановка после 1980 года повлияла на рост числа произведений. Однако стоит отметить, что некоторые произведения этого периода содержат как утопические, так и антиутопические элементы. «Воспоминания о 2027 годе» (2027 Y1lının Anıları) Четина Алтана, «Дети эпохи луча» (Işın Çağı Çocukları) Гюльтен Дайоглу, «Таормина» (Taormina) Хилми Явуза, «Законопроект Йокистана» (Yokistan Tasarısı) Ильхана Мимароглу, «Утопия: Мистический сказочный мир» (Ütopya Mistik Masal Dünyas1) Решата Каракую, «Последняя сказка» (Son Masal) Армагана Этемоглу, «Море черных воспоминаний» (Siyah Hatıralar Denizi) Мехмета Ачара, «Последний остров» Зульфю Ливанели можно отнести к появившимся за последнее время турецким утопиям (Bali ve Uğur 2017: 8-9).

\section{Утопические сны А. Сумарокова и Н. Кемаля}

Будучи первыми авторами, которые использовали мотив сновидений в своих утопических произведениях, А. Сумароков (1717-1777) и Н. Кемаль (1840-1888) являются важными литераторами для своих национальных литератур. Оба автора видят проблемы в социальном порядке и пытаются найти решения этих проблем своими методами, то есть посредством своих произведений. Повесть Сумарокова «Сон 
“Счастливое общество”» была опубликована в 1759 г. в журнале «Трудолюбивая пчела». Н. Кемаль написал свою «Сон» во время изгнания в Магосе в 1872 году. Поскольку работа запрещена, нет четкой информации о процессе публикации (Yürek 2013: 251).

Н. Кемаль не смог получить регулярное образование, но развивался и продолжал свою художественную жизнь благодаря литературным встречам, в которых он участвовал, во время своей службы в Стамбуле. Из-за статей, в которых он поддерживал парламентскую систему, и работ по вопросам родины и свободы, он постоянно испытывал проблемы с государством и много раз был отправлен в ссылку в изгнание (Öztürk 2018: 415). Он написал «Сон» в процессе обновления и вестернизация Османского государства. Увидев приближение социальных перемен, писатель в произведении призывает тихую толпу действовать и освободиться из плена, в котором она находится. Н. Кемаль также рассказывает о предстоящих прекрасных днях и видит, что его мечта о Родине сбывается в конце его сна. С. Стамбулов говорил о «Сне» Н. Кемаля как о «поэтическом произведении» и добавлял, что «это произведение проникло в Туриию, вызвало восторг молодёжи, ходило в сотнях рукописных списков и тайно передавалось из рук в руки» (Стамбулов 1935).

А. Сумароков, который стал одним из самых важных авторов в русской литературе XVIII века, написал произведения разных жанров и внёс большой вклад в литературнохудожественное развитие своей эпохи. Журнал «Трудолюбивая пчела», который он основал в Петербурге в 1759 году, является первым русским частным журналам. В этом журнале автор опубликовал утопическое произведение «Сон “Счастливое общество"». В произведении ощущаются «масонские взгляды, популярные среди интеллектуальной элиты России во второй декаде XVIII века» (Тараканова 2009: 40). Форма правления, рассматриваемая в произведении, «абсолютная монархия, которая управляется просвещенным монархом» (Титлина 2018: 10). Как и в повести «Сон “Счастливое общество"», «в своих произведениях, он выделяет образ справедливого правителя, который поддерживает принципы Просвещения, новые культурные изменения и ведет войну против незнания и реакционности» (İnanır 2008: 160). Цель автора - показать людям основные черты счастливого общества и воспитать дворянское общество.

В текстах «Сон “Счастливое общество”» Александра Сумарокова и «Сон» Намыка Кемаля есть герой-рассказчик. Герой, который видит сны в обоих произведениях, является автором, и события передаются через него. Основная причина этого выбора заключается в том, что в центре художественного вымысла находятся сны. Человек, который лучше всего передаёт сон, несомненно, тот, кто видит этот сон; поэтому используется герой-рассказчик.

Есть параллели с точки зрения художественного вымысла произведений. Обе утопии основаны на сновидении. Другими словами, они построены на бессознательном состоянии. Сумароков начинает, рассказывая свой сон: «Заснув некогда, увидел я в успокоении моём мечтание благополучия общества» (Сумароков 1986: 33). В отличие от Сумарокова, Н. Кемаль подробно изображает место, где он был, прежде чем заснуть: «Однажды днём я пошел в особняк с видом на Босфор и сел у окна» (Kemal 1993: 251). Когда писатель сидит в особняке на в Босфоре, море, которое кажется очень спокойным и тихим, внезапно начинает колебаться, и солнце направляется на запад. Через некоторое время, когда солнце исчезает, мир превращается в темную и страшную среду. В этой 
главе автор, ссылаясь на сложную ситуацию, в которой находится общество, засыпает под влиянием удушья окружающей среды.

А. Сумароков начинает рассказывать об идеальном обществе своей мечты, а не выражать проблемы эпохи: «Благополучия общества, приведенного в такое состояние, какового несовершенство естества достигнуть может» (Сумароков 1986: 33). Н. Кемаль видит во сне общее состояние общества, в котором он живёт: «Я хотел осмотреться. Как будто мои глаза не осмеливались оторваться от моих реснии из-за ужаса ситуачии, я ничего не мог обнаружить (...) Господь, кроме тебя, никто не видит, сколько крови угнетенных пролито за этой темной завесой! Кроме тебя, никто не знает, сколько жестоких людей закаляют свои кинжаль! Кроме тебя, никто не узнает, у скольких сирот слезы текут из глаз! Кроме тебя, никто не слышит, сколько людей, желающих справедливости, плачут из-за угнетателей!» (Kemal 1993: 252). По словам Н. Кемаля, со всех сторон есть жестокость, угнетение, пытки и другие притеснения. Причина всего этого в том, что народ не борется за свободу и Родину.

В отличие от А. Сумарокова Н. Кемаль использует фею свободы, воображаемое существо, для передачи своих идей. Фея свободы, выходящая из горящего облака на горизонте, изображается как довольно красивая женщина. Но когда автор видит цепи, качающиеся за этой красивой женщиной, он понимает, что это образ свободы. Фея свободы обращается к людям: «Эй те, кто ныряют во сне небрежно! Эй те, кто привык к страданиям! Эй те, кто поклоняются плену! Эй те, кто питают унижение страха! Эй те, кто совершают всякое подлость!» (Kemal 1993: 256) и обвиняет этих людей в том, что они безразличны к эпохе и не сопротивляются бедствиям, которые переживает страна, в том, что они приняли плен, укрывшись за достижениями предкам. Она обращается к интеллигенции, трудящейся на благо общества и к тем, кто служит Родине: «Эй надежда Родины, хранитель спасения нации, жизненный капитал достоинства, надежда будущего человечества» (Kemal 1993: 262). Она говорит им продолжать свой путь, несмотря на все трудности, и предвещает, что у них будет величайшее блаженство. Затем фея свободы исчезает. В этой главе Н. Кемаль, через фею свободы, подчёркивает, что вместо того, чтобы связываться с прошлым, необходимо сосредоточиться на будущем. Он приглашает людей действовать, подчеркивая, что поколения интеллектуалов будут добиваться прогресса, не отставая от эпохи.

Утопия Н. Кемаля начинает рассказываться после исчезновения феи свободы. Писатель внезапно оказывается в огромной стране. В первую очередь он видит высоту уровня жизни в обществе и рассказывает об этой ситуации. «Уникальная страна начала демонстрировать своё величие своими городами, равнинами, реками, морями» (Kemal 1993: 263). Он подчёркивает, что страна организована и неописуемо красива. В стране есть города, освещенные цветными лампами и соединенные друг с другом на короткие расстояния. Железные дороги, телеграфные столбы и различные транспортные средства соединяют людей и города.

В обществе все равны. В качестве причины равенства указывается высота уровня образования и благосостояния. В стране есть библиотеки, которыми каждый может воспользоваться. «То, что знает самый недалёкий студент, считается высокой степенью, которая является причиной гордости самых богатых библиотек самой цивилизованной столищы в настоящее время» (Kemal 1993: 264). Народ живёт в 
материальном и духовном изобилии. Поэтому автор говорит, что «даже бедный, который считается самым несчастным, живёт лучше, чем самый богатый султан намего времени» (Kemal 1993: 264).

Уровень жизни общества, который также имеет свободу общения и транспорта, довольно высок. «Имея абсолютное соблюдение права на использование, каждый считал своё имущество ещеё одним миром, созданныл для себя. В каждом доме есть такие объекты, как место для отдыха, библиотека, музей, мастерская, мектеп чтобы удовлетворить все потребности и вкусы семьи» (Kemal 1993: 265).

Система правосудия довольно развита, и свобода мысли стала укоренившейся в утопической стране Н. Кемаля. Нет необходимости искать права, но «суды все ещё служат примером для суда киямата ${ }^{2} »$ (Kemal 1993: 264). Понятие несправедливости даже было удалено из словарей. В этой стране невозможно совершать несправедливость, поэтому «нет необходимости закрывать способы совершения несправедливости железными наборами или вытаскивать каменные стены перед ними или назначать судебных приставов, чтобы справедливость восторжествовала» (Kemal 1993: 264).

Любовь к Родине и обществу лежит в сердцах и душах людей. Все готовы отдать свою жизнь за Родину и общество, но это не нужно. В этой утопической стране, где нет ревности и враждебности, все люди живут в единстве и изобилии. Как видно, в утопии Намыка Кемаля описывается атмосфера полного спокойствия и доверия.

А. Сумароков начинает рассказывать о счастливом обществе, не обращаясь к условиям того периода, в котором он живёт. По его словам, для того чтобы люди были счастливы в стране, общество должно быть в гармонии, обеспечивать эту гармонию идеалистическим и справедливым государственным деятелям. Чтобы изобразить эту среду, Сумароков говорит о системе образования, общественных правилах, моральных ценностях, системе наказания, судах, армии. Но прежде всего он подчёркивает религиозный аспект и духовный мир счастливого общества: «Благочестие, не допускающее примеситься себе суеверию в сей стране, есть основание всего народного благополучия. Духовные содержатся в великом почтении, которого они и достойны» (Сумароков 1986: 33). В утопической стране писателя религиозные и верующие люди показаны как образцовые граждане. Он подчёркивает, что у этих людей обязательно должны быть следующие черты: отсутствие пороков, человеколюбие, скромность и умеренность (Тараканова 2007: 288). Сумароков также упоминает священнослужителей, которые находятся в гармонии с обществом, и изображает их как философов, полезных для общества: «Они к светским и светские к ним имеют любовь, и оттого между духовными и светскими согласие, что на свете бывает редко» (Сумароков 1986: 34). Для автора, который также делает ссылки на Библию в произведении, благочестие является одним из самых основных принципов счастливого общества. Религиозные убеждения Сумарокова отражаются в его утопии, а религиозные мотивы не встречаются в произведении Намыка Кемаля.

\footnotetext{
${ }^{1}$ «Начальная мусульманская школа для мальчиков» (Крысин 2005).

${ }^{2}$ «Как и в христианстве, в исламе существует идея, согласно которой через некоторое время наступит конеч света. За кониом света неизбежно следует так называемый Судный день (Киямат)» (Стогов 2018:14).
} 
Во главе идеальной страны Сумарокова находится тот, кого он описывает как «великого человека». Просвещённый монарх показан как сострадательный и справедливый человек, который любит свою страну: «Сим имеет он народную любовь, страх и почтение. (...) Слабости прощает он милосердно, беззакония наказует строго (...) Достоинство не остаётся без воздаяния, беззаконие без наказания, а преступление без исправления〉 (Сумароков 1986: 33). В то же время монарх посвящает время как работе, так и жизни, но заботится о пользе своего народа, даже когда он развлекается: «Он имеет обыкновение не всегда в делах, но иногда и в забавах упражняться, однако и в них не погубляет он драгоченного времени; обои они на всенародной основаны пользе» (Сумароков 1986: 33). Есть также начальники, которые помогают «великому человеку» в государственных делах. Идеальный государь выбирает «людей честных, разумных и во звании своем искусных» как начальники (Сумароков 1986: 33). В стране существует законодательный государственный орган, называемый Государственный совет, и Сумароков описывает орган следующим образом: «B него никаких участных дел не вносится. Там распорядки, исправления, узаконения и прочие государственные основания или по повелению монарха, или ко предложению оному» (Сумароков 1986: 34).

Сумароков также упоминает законы в идеальной стране. Книга закона, которая привлекает внимание на данный момент, «не больше нашего календаря» (Сумароков 1986: 34) и все общество знает законы наизусть. Счастливое общество идеальной страны не нуждается в законах, состоящих из бесчисленных статей, потому что нет незаконных ситуаций, которые могли бы нарушить порядок. Автор даёт первые и последние предложения в книге законов прописными буквами: «Сия книга начинается тако: ЧЕГО СЕБЕ НЕ ХОЧЕШЬ, ТОГО И ДРУГОМУ НЕ ЖЕЛАЙ. А окончивается: ЗА ДОБРОДЕТЕЛЬ ВОЗДАЯНИЕ, А ЗА БЕЗЗАКОНИЕ КАЗНЬ» (Сумароков 1986: 34).

Другой вопрос, который затрагивает после закона, суды и судопроизводство. Он подчёркивает, что правила соблюдаются в судах, дела заканчиваются быстро и справедливо: «Дела во всех приказах вершатся не по числу голосов, но по книге узаконений, отчего ни споров, ни неправды не бывает. (...) Дела оканчивают очень скоро, для того, что очень мало спорят, а ещё меньще пишут и ни челобитчиков, ни ответчиков лишнего говорить не допускают, а главная причинаскорости их беспристрастие (...) Больше месяча в судебных тамо местах никакое дело не продолжается, а по месяиу времени берут только самые завящивые дела» (Сумароков 1986: 34). По мнению автора, отсутствие несогласий, несправедливости и взяточничества в судах является важным элементом для того, чтобы общество было счастливым и мирным.

Сумароков отмечает, что в счастливом обществе люди равны, крестьянин или вельможа все одинаково приняты: «Не имеют тамо люди ни благородства, ни подлородства и преимуществуют по чинам, данным им по их достоинствам, и столько же права крестьянский имеет сын быть великим господином, сколько сын первого вельможи» (Сумароков 1986: 34). Автор показывает, что люди живут в равных условиях, когда идеальное правительство создано.

Моральные ценности, труд и действия, совершенные на благо общества ценятся: «Всякая наука, всякое полезное упражнение, всякое художество и всякое ремесло, по размеру своея доброты и по размеру успеха трудящегося, тамо в почтении, а 
тунеядство в превеличайшем презрении, а слово тунеядеи жестокая тамо брань, которыл гнушаяся, к работе люди с самого младенчества привыкают» (Сумароков 1986: 35). Также автор подчёркивает, что общество презирает людей с вредными привычками такими, как пьянство, тунеядство, денежные игры.

Еще одна тема, о которой подробно рассказал Сумароков, - военные дела. Все армии зависят от Военного Совета. Он описывает различные звания, которые составляют армию, и упоминает, что обладатели званий должны быть умными и знающими. Народ проявляет любовь и уважение к солдатам, которых они считают защитниками Родины. Армии готовы противостоять любой ситуации, даже в мирное время: «B мирное время войски их непрестанно воинским обрядам обучаются и снабдены всем, во всякое время ко бранному походу готовы. К суровой жсизни военные люди всеми мерами стараются привыкнуть и как защитники отечества народом почитаемы и любимыл (Сумароков 1986: 35-36).

В конце произведений оба писателя испытывают печаль, потому что они пробуждаются от своих прекрасных снов. Когда Н. Кемаль просыпается, хочет снова заснуть, но не может. Он выражает удовлетворение сном, который он видел: «Я видел сон, никакая реальность не сравнится с ним ни разу» (Kemal 1993: 254). Н. Кемаль также указывает на трудность реализации своих идеалов, но это можно увидеть во сне. А. Сумароков тоже недоволен тем, что проснулся от этого прекрасного сна. Он желает, чтобы его сон стал реальностью, которую все видят: «Дай боже, чтобы сны, подобные сну сему, многим виделись, а особливо наперсникам фортуныл» (Сумароков 1986: 36).

\section{Заключение}

В этой статье, в котором сравнивали две разные утопии из мировой литературы, мы пришли к следующим выводам. Н. Кемаль в первую очередь критикует общество своей эпохи. Он не только мечтает, но и объясняет, что нужно для реализации сновидений. Он считает, что его идеализированная Родина может существовать со свободой, волей народа, правительством, ответственной работой каждого и равенством. Он не очень подробно описывает свою идеальную страну, но особенно подчёркивает технологические достижения, важность образования и повышение уровня благосостояния. А. Сумароков начинает рассказывать об идеальном обществе, не подвергая критике и не затрагивая проблем своей эпохи. Он также не указывает, что нужно сделать для появления идеального общества. Он даёт рецепт счастливого общества, описывая общие характеристики идеального государственного деятеля, системы управления и правосудия, армии и общества.

В итоге любое литературное произведение одного и того же жанра уникально изза того, что периоды и ситуации, в которых оно было написано, различны. «Сон “Счастливое общество”» и «Сон», которые являются примерами жанра утопии, имеют много различий, хотя они были написаны в одном и том же жанре. Эта ситуация является конкретным примером отношения литературы к традициям и обществу. Такие факторы, как идеология и личная жизнь автора, социальные и политические условия эпохи, влияют на произведения. Кроме того, эта статья ещё раз демонстрирует важность поиска идеального общества авторами в разных обществах и периодах и вечность жанра утопии. Перспективы дальнейших исследований можно обозначить как выявление различий и 
сходств между русской и турецкой литературами путём сравнительных исследований, а также более подробное изучение развития жанра утопии в обеих литературах.

\section{Etik Beyan}

Yazar beyanına göre, "Первые Утопические Сны в Турецкой и Русской Литературах" adlı çalışmanın yazım sürecinde bilimsel, etik ve alıntı kurallarına uyulmuş; ULAKBİM TRDizin ölçütlerine göre çalışmada etik kurul onayını gerektiren herhangi bir veri toplama ihtiyacı duyulmamıştır.

\section{Библиография}

Balı, Filiz-Uğur, Ufuk (2017). "Yazınsal Alanda Klasik Ütopyalar ve Türk Edebiyatı'nda Ütopya". Dede Korkut, 6 (13): 1-12.

Canbaz Yumuşak, Firdevs (2012). "Ütopya, Karşı-Ütopya ve Türk Edebiyatında Ütopya Geleneğii”. Bilig: Türk Dünyast Sosyal Bilimler Dergisi, 61: 47-70.

İnanır, Emine (2008). I. Petro ve II. Katerina'nın Kanatları Altında XVIII. Yüzyıl Rus Edebiyatı. İstanbul: İskenderiye Yayınları.

Karaca, Birsen (2010). "Yevgeni Zamyatin Ütopya Algılarını Yeniden Kurarken". Folklorledebiyat, 16 (63): 65-70.

Kemal, Namık (1993). "Rüya”. Yeni Türk Edebiyatı Antolojisi. ed. Mehmet Kaplan, İnci Enginün, Birol Emil. İstanbul: Marmara Üniversitesi Yayınları. 251-266.

Nişanyan, Sevan (2021). Nişanyan Sözlük Çağdaş Türkçenin Etimolojisi. https://www.nisanyansozluk.com/?k=\%C3\%BCtopya [16.06.2021].

Öztürk, Zehra (2018). "Veysî’nin 'Hâb-Nâme'si ve Namık Kemal'in 'Rüya'sında Konu, Devir ve Üslup". Researcher: Social Science Studies, 6: 404-421.

Türk Dil Kurumu (2021). Güncel Türkçe Sözlük. https://sozluk.gov.tr/ [16.06.2021].

Yetkin, Gülhanım Bihter (2020). Andrey Platonov'da Ütopya, Yaşamı ve Sanatı (1899-1951). Ankara: İksad Publishing House.

Yürek, Hasan (2013). “Namık Kemal ve Ziya Paşa'nın ‘Rüya'ları”. Türk Dünyası İncelemeleri Dergisi, XIII (2): 249-263.

Бугров, Дмитрий Витальевич (2001). "Утопия в России: к истории развития литературного жанра во 2-й половине XVIII - 1-й трети XX в.”. Русская литература: национальное развитие и региональные особенности: Материаль международной научной конференции: $B$ ч 2 ч. Ч. 1. Екатеринбург: Уральский федеральный университет им. Б.Н. Ельцина. 31-40.

Веремчук, Алла Сергеевна-Сорокин, Геннадий Вениаминович (2017). "Утопизм в сознании русской интеллигенции XIX - начала XX века”. Известия высших учебных заведений, Северо-Кавказский регион, Общественные науки, 2 (194): 9-15.

Егоров, Борис Федорович (2007). Российские утопии: исторический путеводитель. Санкт-Петербург: Искусство. 
Крысин, Леонид Петрович (2005). Толковый словарь иноязычных слов. Москва: Издательство Русский язык.

Митина, Наталья Георгиевна (2013). "Русская утопия. Территория новых возможностей". Вестник Владивостокского государственного университета экономики и сервиса, 1 (19): 15-24.

Святловский, Владимир Владимирович (2015). Русский утопический роман (Фантастическая литература: Исследования и материалы. Том II). Москва: Salamandra P.V.V.

Стамбулов, Виктор Осипович (1935). Намык Кемаль. Москва: Журнально-газетное объединение.

Стогов, Дмитрий Игоревич (2018). Ислам: история и современность: учебное пособие по дисииплине «Религиоведение». Санкт-Петербург: Издательство СПбГЭТУ «ЛЭТИ».

Сумароков, Александр Петрович (1986). “Сон 'Счастливое Общество”,. Русская литературная утопия. ред. Вячеслав Павлович Шестаков. Москва: Издательство Московского университета. 33-36.

Тараканова, Анна Дмитриевна (2007). "Утопический идеал в произведении А. П. Сумарокова «Сон. Счастливое общество»". Дергачевские чтения - 2006. Русская литература: начиональное развитие и региональные особенности: материаль международной научной конференции. 5-7 октября 2006 г. Екатеринбург: Издательство Уральского университета; Издательский дом «Союз писателей». 287292.

Тараканова, Анна Дмитриевна (2009). "Русская литературная утопия второй половины XVIII века". Ученые записки Казанского университета, Серия Гуманитарные науки, 151 (3): 39-46.

Титлина, Елена Юрьевна (2018). “Повесть А.П. Сумарокова «Сон “Счастливое Общество"» как явление русской утопической мысли середины XVIII в.”. Вестник Амурского Государственного Университета, Серия: Гуманитарные Науки, 80: 8-15.

Юрченко, Татьяна Генриховна (2018). "Утопический дискурс в русской литературе XXXXI вв.”. Сочиальные и гуманитарные науки, Отечественная и зарубежная литература, Сер. 7, Литературоведение: Реферативный журнал, 4: 192-198.

\section{References}

Balı, Filiz-Uğur, Ufuk (2017). "Yazınsal Alanda Klasik Ütopyalar ve Türk Edebiyatı'nda Ütopya". Dede Korkut, 6 (13): 1-12.

Canbaz Yumuşak, Firdevs (2012). "Ütopya, Karş1-Ütopya ve Türk Edebiyatında Ütopya Geleneği”. Bilig: Türk Dünyası Sosyal Bilimler Dergisi, 61: 47-70.

İnanır, Emine (2008). I. Petro ve II. Katerina'nın Kanatları Altında XVIII. Yüzyıl Rus Edebiyatı. İstanbul: İskenderiye Yayınları. 
Karaca, Birsen (2010). "Yevgeni Zamyatin Ütopya Algılarını Yeniden Kurarken". Folklor/edebiyat, 16 (63): 65-70.

Kemal, Namık (1993). "Rüya". Yeni Türk Edebiyatı Antolojisi. ed. Mehmet Kaplan, İnci Enginün, Birol Emil. İstanbul: Marmara Üniversitesi Yayınları. 251-266.

Nişanyan, Sevan (2021). Nişanyan Sözlük Çağdaş Türkçenin Etimolojisi. https://www.nisanyansozluk.com/?k=\%C3\%BCtopya [16.06.2021].

Öztürk, Zehra (2018). "Veysî’nin 'Hâb-Nâme'si ve Namık Kemal'in 'Rüya'sında Konu, Devir ve Üslup". Researcher: Social Science Studies, 6: 404-421.

Türk Dil Kurumu (2021). Güncel Türkçe Sözlük. https://sozluk.gov.tr/ [16.06.2021].

Yetkin, Gülhanım Bihter (2020). Andrey Platonov'da Ütopya, Yaşamı ve Sanatı (1899-1951). Ankara: İksad Publishing House.

Yürek, Hasan (2013). "Namık Kemal ve Ziya Paşa'nın “Rüya”ları”. Türk Dünyası Íncelemeleri Dergisi, XIII (2): 249-263.

Bugrov, Dmitriy Vital'evich (2001). "Utopiya v Rossii: k istorii razvitiya literaturnogo janra vo 2-y polovine XVIII - 1-y treti XX v.". Russkaya literatura: natsional'noe razvitie $i$ regional'nye osobennosti: Materialy mejdunarodnoy nauchnoy konferentsii: $V 2$ ch. Ch. 1 . 10-11 oktyabrya 2000 g. Yekaterinburg: Ural'skiy federal'nyy universitet im. B.N. Yel'tsina. 31-40.

Veremchuk, Alla Sergeevna - Sorokin, Gennadiy Veniaminovich (2017). "Utopizm v soznanii russkoy intelligentsii XIX - nachala XX veka”. Izvestiya vysshikh uchebnykh zavedeniy, Severo-Kavkazskiy region, Obshestvennye nauki, 2 (194): 9-15.

Yegorov, Boris Fedorovich (2007). Rossiyskie utopii: istoricheskiy putevoditel'. SanktPeterburg: Iskusstvo.

Mitina, Natal'ya Georgievna (2013). "Russkaya utopiya. Territoriya novykh vozmojnostey". Vestnik Vladivostokskogo gosudarstvennogo universiteta ekonomiki i servisa, 1 (19): 1524.

Krysin, Leonid Petrovich (2005). Tolkovyy slovar' inoyazychnykh slov. Moskva: Izdatel'stvo Russkiy yazyk.

Svyatlovskiy, Vladimir Vladimirovich (2015). Russkiy utopicheskiy roman (Fantasticheskaya literatura: Issledovaniya i materialy. Tom II). Moskva: Salamandra P.V.V.

Stambulov, Viktor Osipovich (1935). Namyk Kemal'. Moskva: Jurnal'no-gazetnoe ob'edinenie.

Stogov, Dmitriy Igorevich (2018). Islam: istoriya i sovremennost': uchebnoye posobie po discipline «Religiovedenie». Sankt-Peterburg: Izdatel'stvo SPbGETU «LETI».

Sumarokov, Aleksandr Petrovich (1986). "Son "Schastlivoe Obshestvo"”. Russkaya literaturnaya utopiya. red. Vyacheslav Pavlovich Shestakov. Moskva: Izdatel'stvo Moskovskogo universiteta. 33-36. 
Tarakanova, Anna Dmitrievna (2007). "Utopicheskiy ideal v proizvedenii A. P. Sumarokova «Son. Schastlivoe obshestvo»". Dergachevskie chteniya - 2006. Russkaya literatura: natsional'noe razvitie $i$ regional'nye osobennosti: materialy mejdunarodnoy nauchnoy konferentsii. 5-7 oktyabrya 2006 g. Yekaterinburg: Izdatel'stvo Ural'skogo universiteta; Izdatel'skiy dom «Soyuz pisateley». 287-292.

Tarakanova, Anna Dmitrievna (2009). "Russkaya literaturnaya utopiya vtoroy poloviny XVIII veka". Uchenye zapiski Kazanskogo universiteta, Seriya Gumanitarnye nauki, 151 (3): 3946.

Titlina, Yelena Yur'evna (2018). "Povest' A.P. Sumarokova «Son "Schastlivoe Obshestvo"» kak yavlenie russkoy utopicheskoy mysli serediny XVIII v.". Vestnik Amurskogo Gosudarstvennogo Universiteta, Seriya: Gumanitarnye Nauki, 80: 8-15.

Yurchenko, Tat'yana Genrikhovna (2018). "Utopicheskiy diskurs v russkoy literature XX-XXI vv.". Sotsial'nye i gumanitarnye nauki, Otechestvennaya i zarubejnaya literatura, Ser. 7, Literaturovedenie: Referativnyy jurnal, 4: 192-198. 